\title{
The Effective of Task Based Instruction in Improving Learners' Speaking Skills: The Case of Micha Preparatory School
}

\author{
Mesfin Girma kebede(M.A) \\ Department of English Language and Literature, Madda Walabu University, Bale Robe, Ethiopia \\ Zeleke Regessa Gindo(PhD.) \\ Department of English Language and Literature, Madda Walabu University, Bale Robe, Ethiopia \\ Kemal Nure Kawo(M.Sc.) \\ Department of Statistics, Madda Walabu University, Bale Robe, Ethiopia
}

\begin{abstract}
The main objective of this study is to investigate whether TBI had an effect on the speaking performance of EFL students of grade eleven at Micha Preparatory School. To achieve this, quasi-experimental research design and mixed research method were employed. From the total population of twelve section of grade 11 students, two sections with a total of 84 students were selected randomly as control and experimental group respectively. To investigate students' perceptions towards TBI, questionnaire and interview were used with the experimental group. The collected data were statically analyzed by employing SPSS version 20, T-test, P value, Tables and Percentages for the respondents' trends analyzed. The data were analyzed using both quantitative and qualitative procedures. The analysis of the students' pre-oral tests showed no significant difference in the overall speaking performance between the experimental and control group students. However, in the post -oral test there was a significant difference between these groups in features of speaking. The results of the questionnaire and interview revealed that the experimental students had positive attitude towards the practice of speaking skill by using TBI. Based on the findings, it was suggested that TBI should be used primarily to encourage students to make their speech accurate and fluent learning speaking.
\end{abstract}

DOI: $10.7176 / \mathrm{JEP} / 10-34-02$

Publication date: December $31^{\text {st }} 2019$

\section{Introduction}

\section{Background}

Currently, in many parts of the world a speaking knowledge of English language has become essential in academic studies, professional success and personal development. Willis, (2007) reveals that English is the language that expanded breaking the barriers of color, race and belief, and has continued to spread all over the world. As a result, it has become the language of international affairs. English has become the language that links the world all together. It is the medium through which technological, social, political and cultural information has been transmitted. In the Ethiopian educational system, the learning of English begins at KG the level and it gives different functions at various organizations. A document from the Federal Ministry of Education (2007:1) also reveals "English is a corner stone in the development of Ethiopia's commerce, communication systems, technology and education".

Speaking is one of the skills which enable communication. It is a fundamental skill of transmitting meaning and knowledge. Willis (2004) explains that speaking is a process of constructing meanings that involves producing, receiving and processing information. Speaking in English language is a strong need for everybody and an important component of language course where communicative language teaching is applied. However, as Sinatra, (2009) notes it is more difficult to design and administer speaking tasks than to do so for listening, reading or writing. Considerable number of students in high schools of our country is not actively participating in speaking activities. Most of the students know the rules of the language, but they usually fail to communicate using the language. (Ministry of Education, 2004) stated that the status of English is very low in Ethiopian schools at all levels. Although the challenges are found in all language skills, the challenges in speaking skills are more serious when compared to other skills because of different challenges that influence teachers' teaching productively and the students' speaking performance such as inappropriate teaching methodology, students' low motivation in learning English, classroom size, arrangement of desks and limited time of teaching learning process.

However, there are surely various factors that affect teaching speaking skills in EFL classes that make students communicative competence unsatisfactory. A traditional limitation to developing students' communicative competence is the inadequate interaction between teachers and students. Teachers simply spend much time lecturing while students take notes and seldom participate in class (Tirualem, 2003). In other words, most of the teachers still use the traditional methods of teaching English so that teachers seldom set up 
interesting activities to encourage their students to have active and effective English learning. Task based instruction approach overcomes many of the criticisms of communicative language teaching approach particularly speaking skill of students. Task-based instruction can be defined as an approach in which communicative and meaningful tasks play central role in language learning and in which the process of using language appropriately carries more importance than the mere production of grammatically correct language forms (Oliveira, 2004). Therefore, TBI has many advantages. One of these advantages is that tasks are more student-centered and allow for more meaningful communication. Such tasks often help the learner to gain practical extra-linguistic skill building. They also give the learners the chance to make use of the language resources they possess in a creative way. Tasks can provide the learner with new personal experience to be able to use the target language in order to solve a problem, come to an agreement or communicate some messages. In so doing, learners stretch their linguistic knowledge and communicative skills to the maximum. Another advantage of task based instruction is that doing tasks maintains learner autonomy. During the performance of tasks, learners are obliged to use a number of language learning strategies such as compensation strategies, communication strategies or cognitive strategies (Oura, 2001). Carrying out communicative tasks creates conditions necessary for greater autonomy on the part of the learner since the learner has to make a lot of decisions connected with language use.

To practice this approach in speaking classroom, much is expected from EFL Teachers. If teachers follow the procedures suggested in the current English language teaching literatures, it certainly contributes to the success of the teaching of speaking. As indicated above, one of the challenges of task-based learning and instruction is that engaging students in a variety of tasks is necessary to promote acquisition. Students have many pedagogical needs which often necessitate different techniques for active engagement of learning speaking skill by using TBI. Besides, to bring this active engagement, it is essential for teachers to select materials that suit their learners' needs and interest Willis, (2007).

However, as the researcher has made preliminary observation in the school he has been teaching and found that teaching of speaking skill using task based language teaching approach is not being efficiently undertaken in Micha Preparatory Schools. Moreover, the lack of speaking skill developing resources also holds in this preparatory schools, there was too much focus on teaching grammar and very little was done to improve students' speaking skill. Furthermore, the researcher observed from his experience students had difficulties doing speaking tasks as expected according to their level. The problems were identified while the researcher was at work. Therefore, the above mentioned conditions initiated the researcher to conduct a study on to examine different challenges and practices of TBI seen in the teaching learning of speaking skill in implementing TBI through speaking tasks. Therefore, the researcher concluded that it is important to study EFL teachers and learners' practices and challenges of implementing TBI approach in the speaking classroom to address the problem for a recommended possible solution scientifically which was studied in a research. Thus, this study investigates the effectiveness of task based instruction in improving learners' speaking skill in EFL classroom at Micha Preparatory School Grade 11 students' in focus, because among other skills speaking skill is the great problem in the given school.

\section{Statement of the Problem}

The current curriculum of English for Ethiopia provides a fairly sufficient amount of content and time for teaching speaking skill by using different language teaching approach especially in secondary level. English language is used as a medium of instruction beginning from Grade 7, in some parts like in southern nation, nationalities and Amhara regional state as well as Addis Ababa city administration and from Grade 9 in all parts of the country. This encourages students to give more attention towards learning the language. Furthermore, the access of satellite television lessons of English is one of the good opportunities that English language teachers have to help students enhance their speaking skills in secondary and preparatory. Here, exposing learners to speak native speakers' accents by using the target language and practicing different speaking tasks help them for recognizing the different features of spoken language.

As an English teacher, the researcher has made preliminary observation in the school he has been teaching and found that English language teachers are not using the task based language teaching approach effectively. Whereas, in using TBI in the speaking classroom students develop a language system through attempting to use a meaning based language. Teachers design an opportunity for the students' meaningful, authentic and interesting activities (Ellis, 2003). The students have much more varied exposure to the language and all of language issues that they need.

Learners spend a lot of their time in communicating during the task (Meseret, 2013). The intended outcomes that should be revealed from the implementation of TBI approach in speaking classroom were not seen satisfactorily in this school, where the study was conducted. In addition, students were not working hard in improving their speaking skill by using this approach and implementing speaking tasks. It seems that from the researcher experience this happened because of lack of interest on part of the students, or lack of sufficient guidance for students from the teachers. It would be answered by the research. 
Researches in the area of the effectiveness of TBI in improving learners speaking skill had been conducted by different researchers. For instance, the research on the effect of task-based instruction in the improvement of learners reading and writing skills by (Rubaiat, 2018) found that task based language teaching plays a significant role to improve learners' reading and writing skills. (Abdelmajid, 2017), implementing task based language teaching in Sudanese EFL context also found that implementing task based language teaching was essential for EFL language learners to develop their communicative skills. An analysis of the speaking tasks of English for Ethiopia textbook by (Meseret, 2013) found that role of learners and teachers are not explicitly stated in the textbook, but they are stated in the teacher's guide. This means that students may get it difficult to know their roles in performing specific tasks in a given activity and (Tagesse, 2008) the practicability of task-based instruction in EFL classroom in higher institute is found out that task-based instruction is being practiced to some extent in higher institutes, though the basic principles of the approach are not followed etc are worth mentioned.

The one that is closer to the present study is the study which was conducted by (Baris, 2005), which was the effectiveness of TBI in improving learners speaking skill however the research only checked factors which are affecting the effectiveness of the approach through communicative tasks in higher institute. But, the present research is different from the research conducted by (Baris, 2005), in that it gave more emphasized to see the effectiveness of TBI in improving learners speaking skill in EFL classroom. Not only this but also it differs from this research in terms of time, complexity, grade level and place. Thus, the present study checked up the effectiveness of TBI in improving learners speaking skill in Micha Preparatory School grade 11 students in focus in EFL classroom.

\section{Objectives of the Study}

The main objective of this study is to investigate the effectiveness of task based instruction in improving learners' speaking skills.

\section{Specific Objectives}

- To find out the relationships between teachers' teaching of speaking activities through TBI with grade 11 students in using English language for communication purposes or not.

- To examine whether TBI can improve student's speaking skill or not.

- To check whether the teachers use communicative task based instruction techniques and activities in EFL classroom effectively or not.

- To see whether Learners feel satisfied when the teacher uses the techniques of task based instruction or not. Significance of the study

It gives for the English language teachers an opportunity to examine how far they went to implement the techniques or methods of TBI in teaching speaking skill, to provide support for their students on principles of TBI for learning their speaking and how to improve speaking skills by implementing it.

It will help learners to identify their problems on using different principles and techniques of TBI to improve their speaking skill.

It will be valuable for syllabus designers to speculate some practical problems seen in the practice and hence improve it in order to support learners to enhance their speaking skill.

It may be helpful for other researchers who want to use the findings of this research as bases for further researches in the area.

\section{Research Design and methodology}

The major aim of this study was to investigate the effectiveness of task-based instruction in the improvement of learners' speaking abilities. Since the objective of the study need both quantitative and qualitative data, the study employed quasi-experimental research design as mixed methods research that allows us to triangulate data and the findings, which can strengthen the research validity. (Creswell, 2002) stated that mixed method approach is an inquiry strategy that is focused on triangulating different qualitative and quantitative data. These help the researcher to provide a data what have been explored. (Sandelewski, 2003) as cited in (Zoltan, 2007) stated that there are two main conflicting purposes for combining methods. These are to achieve comprehensive understanding of a target phenomenon and to verify one set of findings against the other.

Both the experimental and the control group students were taught by the researcher. The experimental group was taught speaking skill by using the task-based instruction (TBI) and the control group was taught using the conventional method of teaching. The researcher had 8 years of teaching experience at the preparatory level.

An equivalent pre and post-test were given to the two groups before and after the treatment. The tests are adopted from the student's textbook currently in use for the grade level. Furthermore; the researcher used a qualitative method of analysis to measure the effectiveness of communicative task-based instruction.

\section{Population of the Study}

The target population of this study was all twelve sections of grade eleven students' sections $11^{\text {th }}$ A-L (504 students) who was be registered in first semester the academic year 2011 E.C. and their five English language 
teachers who were teaching at Micha Preparatory School were assigned as the subject of the study.

\section{Sample size and Sampling Techniques}

According to Morrison, 2001b the size of a probability (random) sample can be determined in two ways, either by the researcher exercising prudence and ensuring that the sample represents the wider features of the population with the minimum number of cases or by using a table which, from a mathematical formula, indicates the appropriate size of a random sample for a given number of the wider population. Accordingly, out of total 12 sections of grade 11 students, the representative samples were taken as the subjects of study. Taking all students as subject was not manageable in terms of time and finance. Therefore, as Morrison, (2001b) states from the researcher exercising prudence and experiences, the researcher utilized to choose two sections (84) students from twelve sections of $11^{\text {th }} \mathrm{A}$ up to $\mathrm{L}$. Each section has 42 students. From these, sections $11^{\text {th }} \mathrm{D}$ and $11^{\text {th }} \mathrm{L}$ students were selected randomly as control and experimental group respectively. In order to minimize the personal bias between the two groups in marking the pre and post-test the researcher used purposive sampling technique to choose two English teachers from five English teachers who were teaching grade 11at Micha Preparatory School.

\section{Data Collection Instruments}

The following instruments were employed for generating the information that could address the purpose of the study. In order to collect the data in this study, pre- and post- oral tests, questionnaires, and interviews were used with the control and experimental group of students.

Tests

Oral texts produced by the students in both groups were used to find out the difference in speaking performance between the two groups. Students were made different pair dialogues on different topics before and after the treatment of teaching speaking skill by using TBI. Both groups were instructed to produce the pair dialogues within two minutes for each pair. For two English teachers I gave orientation to check with seven features and marked the oral texts produced by students in both groups which were recorded audio visually. This marking scale was used as it helps to address how a student performs on seven speaking features: task achievement, fluency, discourse management, vocabulary, grammar, interactional skill (sensitivity to turn taking, maintaining flow of conversation), and pronunciation (accent, stress, intonation). For five speaking feature (task achievement, fluency, discourse management, vocabulary, grammar, has out of $20 \%$ marks and two speaking feature (interactional skill (sensitivity to turn taking, maintaining flow of conversation), and pronunciation (accent, stress, intonation) has out of $10 \%$ it generally was out of $30 \%$ marks, on which a given oral text was evaluated.

The pre-oral tests were used to check if the two groups were at the same level of speaking performance at the beginning of the study. In the pre-oral tests students were making conversation on specific task based on the English text book for grade 11currently in use on given topics.

Post-oral tests were conducted after the experimental and the control group students were taught speaking activities through TBI and conventional method respectively for three months. After both groups were taught speaking skill by using the methods mentioned above they were taken post- oral tests. The purpose of the postoral test activities was to see if TBI brings any change in the students speaking performance. The pre and postoral test results of both groups were used for analyses by using SPSS version 20 software techniques to obtain accurate and perfect results.

\section{Questionnaire}

As Sharma (2000) stated that a questionnaire enables a researcher to administer a number of subjects in one place at a time. The questionnaire was selected not only because it was the most common data gathering tool but also it helps to collect a great deal of information within short time limit and helps to reach large group of research subjects. A set of questionnaire consisting of fifteen closed ended items was designed for this thesis to support the data obtained from the test analysis. It was meant to assess the experimental group students' general reflection on the TBI practice they had been taking part in. The questionnaire was designed in such a way that the students rate the extent to which they agree or disagree on a given TBI-related statement, and express their feelings and perceptions about the speaking activities. Items 1-15 were answered on a five-Point-Likert scale from strongly agree to strongly disagree.

Items 1-5 raised issues of the importance of TBI for the students in a general way. Items 6-10 dealt with students' perceptions towards quality of TBI in improving form, content and both, and the degree to which the students accept comments, and the usefulness of TBI from the teacher and students' point of view. Items 11-15 dealt with students' affective benefit of TBI in making students active, confident, and their general feelings towards TBI. Responses from these questionnaires would answer the hypothesis on students' feelings and excited about the uses of TBI in EFL speaking classroom.

\section{Interview}

Interview was another instrument in the study. Semi-structured interview would be conducted with 10 learners, 5 females and 5 males were selected purposively from the experimental group after task based teaching of 
speaking skill treatment by the researcher. The interview had ten questions dealing with students' general attitudes towards the TBI they had been practicing. This was to assess the role of this TBI in improving students speaking. This interview would be also conducted in order to have learners' detailed ideas and feelings about task-based instruction after the treatment and after their post-oral test sessions. The data from this interview would be used to respond to the hypothesis in respect to student attitudes and feelings towards task based instruction.

\section{Materials}

The material used in this study would be training manual on task based instruction of speaking skills and the official text book of Grade 11 published by the Ministry of Education 2002 E.C. English for Ethiopia student text book grade 11 would be used as the main course book for the two groups. The training manual would be prepared and taught by the researcher. The training would be given only for the treatment groups.

Procedure of the Study

The procedures of this experimental study were briefly presented as follow:

Stage 1: A pre-oral test was given to student respondents of grade 11 before the treatment of teaching speaking skill through TBI for experimental groups. The purpose of this test was to identify the variance of the performance of their speaking skill among the two groups.

Stage 2: The treatment stage would be given after both groups were given the pre-oral test, in the treatment speaking phase, the researcher taught speaking skill through TBI for the experimental group and using the conventional method for the control group for three months to help the experimental group dealt with the process of task based instruction in improving learners speaking skills.

Stage 3: Both experimental and control groups were given a post-oral test at the end of the treatment of teaching speaking skill through TBI to evaluate their achievement whether the task-based instruction is effective or not in improving their speaking skills of the experimental group.

Stage 4: The score of the pretests and posttests, questionnaires and interviews collected from the experimental and control groups were analyzed. Then the conclusions and recommendations were made for further research.

\section{Method of Data Analysis}

The approaches of the research contain both quantitative and qualitative methods. Data collected by questionnaire and tests were putted, calculated and organized in tables quantitatively in terms of number, percentage, mean, and standard deviation whereas, the data collected through interviews would be analyzed qualitatively in terms of words to strengthen the subjects 'responses from the questionnaire. Then, the findings from qualitative and quantitative data was merged. Then finding of the two data gets would be interpreted using quantitative and qualitative data analysis to provide the overall findings of the study.

The two major statistical sample T-tests used for this study in pre and post tests were explained as follows:

\section{Independent Sample T- test}

The independent-sample $t$ test is used to compare two groups' scores on the same variable. The groups should be randomly drawn from normally distributed and independent populations. In this study it was used to compare the groups of students which were control group and Experimental group to evaluate whether there is a difference in their performance of speaking English due to the task based instruction which was taught the speaking skill for the experimental group students. The t-value is calculated as follows:

$$
t=\frac{(\bar{X}-Y)-\left(\mu_{1}-\mu_{2}\right)}{\sqrt{\frac{S_{1}^{2}}{n_{1}}+\frac{S_{2}^{2}}{n_{2}}}},(1-\alpha) 100 \% C I \text { can be given as: }\left((\bar{X}-\bar{Y}) \pm t_{\alpha / 2}^{\left(n_{1}+n_{2}-2\right)} \sqrt{\left.\frac{S_{1}^{2}}{n_{1}}+\frac{S_{2}^{2}}{n_{2}}\right)}\right.
$$

Two Sample Paired T-test

T-tests compare the means of two samples. When each element of a sample is matched to its corresponding element of the other sample, two samples are paired. This paired t-test examines the mean of individual differences of paired measurements and thus is appropriate for pre-post situations. The aim of a study was to investigate the effectiveness of a task based instruction in improving learners speaking skill used pre and posttest. The paired t-test is based on the pair wise differences in values of matched observations of two samples $d_{i}=y_{1 i}-$ $\mathrm{y}_{2 \mathrm{i}}$. The difference of matched pairs is treated as a variable. The test statistics and mean paired mean difference are:

$t_{\bar{d}}=\frac{\bar{d}-D_{o}}{s_{d}} \sim \mathrm{t}(\mathrm{n}-1)$, where $\bar{d}=\frac{\sum d_{i}}{n}, s_{d}^{2}=\frac{\sum\left(d_{i-a}\right)^{2}}{n-1}$ and $s_{\bar{d}}=\frac{s_{d}}{\sqrt{n}}$

The null and alternative hypothesis is

Ho: $\mu_{\mathrm{d}}=\mathrm{D}_{\mathrm{o}} \quad \mathrm{VsH}_{1}: \mu_{\mathrm{d}} \neq \mathrm{D}_{\mathrm{o}}$

The null hypothesis is that the paired mean difference of the students after and before tests were taught speaking 
skill by using task based instruction is zero. Rejected the null hypothesis if the calculated test statistics is greater than the tabulated t-values (if the P-value $<0.05$ ), otherwise do not reject null hypothesis.

\section{Results and discussion}

The main purpose of this study was to investigate the effectiveness of task based instruction in improving learners speaking skills. A test tool was used for collecting and investigating data in order to get the required purposes of the study and also to check the hypotheses of the study, some statistical methods were used such as independent sample $t$ test and paired $t$ test were used to analyze the data. To obtain accurate and perfect results characterized by a high accuracy as well as possible, SPSS (Statistical Package for Social Sciences) technique was used to analyze data.

\section{Students' Speaking Performance at the Beginning of the Study}

Students took the exam in pairs which was designed by the researcher. The tests comprised role-playing tasks. Each pair was required to choose a slip from an envelope and read it aloud so that the other member of the pair would know their role. On the slips, there were different situations. Students on their own were expected to prepare a conversation based on the chosen slip in two minute. When they were ready, they started the conversation and the raters observed them. Students repeated the same procedure for another set of situation slips. After students finished the role-playing and left the classroom, raters scored their performance individually by using the current oral assessment rubric. In the following Table, the summary of the results of both groups was given. In order to find out if there was a significant difference in speaking performance between the two groups a comparison was made using independent sample t-test.

Table 1: Pre-Oral Test Speaking Performance Scores of Group 1 and Group 2

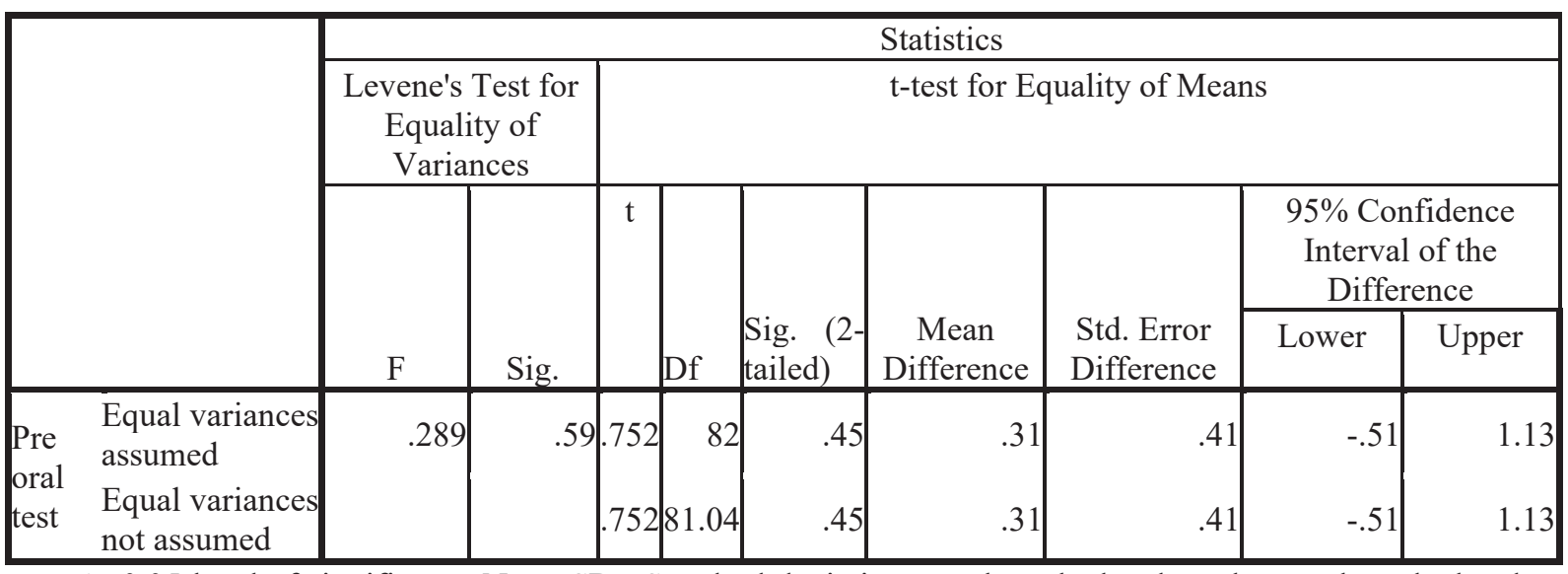

At 0.05 level of significance Note: $\mathrm{SD}=$ Standard deviation $\mathrm{t}=$ the calculated $\mathrm{t}$-value $\mathrm{p}=$ the calculated $\mathrm{p}$ value. The above table results of Independent Samples T-test indicate that the p-value is 0.45 which is greater than 0.05 , we do not reject null hypothesis and hence, conclude that there is no significant difference in speaking performance between the two groups at the beginning of the study. Hence, this could be evident to claim that the students were nearly at the same level of speaking performance before the treatment of teaching speaking skill by using TBI for the experimental group students.

\section{Students' speaking features performance at the beginning of the study}

To find out the level of difference in performance between the groups in the seven speaking features, a comparison was made using the independent sample -test analyses as follows.

Table 4: Pre-Oral Test Speaking Features Performance Scores of Group 1 and Group 2

At 0.05 level of significance

As shown in table 4.2, indicate that the calculated p-value of each speaking features was greater than $t$-value of significance at 0.05 Thus, indicated there was no significant difference between the groups in speaking features performance at the beginning of the study. On the other hand, the t-test shows that there was no significant difference observed between the control and the experimental group in terms of all features speaking of which their $\mathrm{p}$ - value are greater than the critical $\mathrm{t}$-value $(2, \mathrm{df}=82)$ set at 0.05 level of significance. Thus, indicated there was no significant difference between the groups in speaking features performance at the beginning of the study. The groups were relatively at a similar level of performance in each speaking feature.

Speaking Features Performance after the Treatment of Teaching Speaking Skill through TBI to the Experimental group

To find out how the groups were performing in the seven speaking features, each group was compared by taking each speaking feature into account. Then, the independent sample t-test was calculated to find out the level of difference between the groups in each feature. 
Table 2 Post-Oral Test Speaking Features Performance Scores of Group 1 and Group 2

\begin{tabular}{|c|c|c|c|c|c|c|c|c|c|}
\hline \multirow[t]{3}{*}{ Item } & \multicolumn{2}{|c|}{$\begin{array}{l}\text { Levene's Test } \\
\text { for Equality of } \\
\text { Variances }\end{array}$} & \multicolumn{7}{|c|}{ t-test for Equality of Means } \\
\hline & \multirow[t]{2}{*}{$\mathrm{F}$} & \multirow[t]{2}{*}{ Sig. } & \multirow[t]{2}{*}{$\mathrm{T}$} & \multirow[t]{2}{*}{$\mathrm{df}$} & \multirow[t]{2}{*}{$\begin{array}{l}\text { Sig.(2- } \\
\text { tailed) }\end{array}$} & \multirow[t]{2}{*}{$\begin{array}{l}\text { Mean } \\
\text { difference }\end{array}$} & \multirow[t]{2}{*}{$\begin{array}{l}\text { Std.Error } \\
\text { Difference }\end{array}$} & \multicolumn{2}{|c|}{$\begin{array}{l}95 \% \\
\text { Confidence } \\
\text { Interval }\end{array}$} \\
\hline & & & & & & & & Lower & Upper \\
\hline Task achievement & 1.20 & .27 & -.39 & 82 & .69 & -.06 & .15 & -.36 & .24 \\
\hline Fluency & .00 & .98 & .87 & 82 & .38 & .12 & .14 & -.15 & .39 \\
\hline Discourse Management & 1.24 & .27 & .30 & 82 & .76 & .04 & .12 & -.19 & .27 \\
\hline Vocabulary & .66 & .42 & -1.18 & 82 & .24 & -.14 & .12 & -.38 & .09 \\
\hline Grammar & 1.09 & .29 & -.54 & 82 & .59 & -.06 & .11 & -.28 & .16 \\
\hline Interactional skill & 2.23 & .14 & 1.46 & 82 & .15 & .18 & .12 & -.06 & .42 \\
\hline Pronunciation & .18 & .67 & -1.54 & 82 & .13 & -.17 & .11 & -.38 & .05 \\
\hline
\end{tabular}

HO: There is no statistically significant relationship between teacher's teachings of speaking activities through TBI and grade 11 students in English language use for communication purposes.

H1: There is statistically significant relationship between teacher's teachings of speaking activities through TBI and grade 11 students in English language use for communication purposes. As indicated in Table 4.3, the speaking features which were significantly improved were that of the experimental group in which the improvement was in all the speaking features as the observed p-values of all features are 0.00 which are less than the table value of $\mathrm{t}(2, \mathrm{df}=82)$ set at 0.05 level of significance. Thus, indicated there was significant difference between the groups in speaking features performance after the treatment of teaching speaking skill through TBI for those of the experimental group.

These analyses revealed that task based instruction teaching of speaking skill had a significant effect on the speaking performance in all speaking features. It was found out that task based instruction have a significant effect in all speaking features. This finding confirms the result obtained from the analyses of students' TBI comments and practicing role play in pair enough, the experimental group appeared to perform better. Hence, task based instruction brought a speaking performance difference between the groups by enabling the experimental group to improve the task achievement, fluency, discourse management, vocabulary, grammar, interactional activity and pronunciation of their speaking skill. That means, attributing the changes in the speaking performance to these speaking features, it is possible to say that task based instruction has a direct relationship with teaching of speaking as these all features of speaking skill were improved due to this method of instruction. Thus, the null hypothesis was rejected.

\section{Students' Overall Speaking Performance after the Treatment Teaching of Speaking through TBI}

The two groups' overall speaking performance is the sum total of the speaking features. The p-values scores of both groups speaking performance were summarized as follows.

To find out if the two groups were performing differently or in the same way, a comparison was made using the independent sample t-test. Now, again let us revise the hypotheses raised at the beginning of this study and verify them.

Ho: There is no significant difference in the speaking performance between the control group and experimental group students.

H1: There is a significant difference in the speaking performance between the control group and experimental group students.

To test the above hypotheses, the post-oral test speaking performance p-values of the control and the experimental group were compared. 
Table 3 Post-Oral Test Speaking Performance p- values of Group 1 and Group 2

\begin{tabular}{|c|c|c|c|c|c|c|c|c|c|c|}
\hline & \multicolumn{2}{|c|}{$\begin{array}{c}\text { Levene's Test for } \\
\text { Equality of } \\
\text { Variances }\end{array}$} & \multicolumn{7}{|c|}{ t-test for Equality of Means } \\
\hline & & \multirow[t]{2}{*}{$\mathrm{F}$} & \multirow[t]{2}{*}{ Sig. } & \multirow[t]{2}{*}{$\mathrm{T}$} & \multirow[t]{2}{*}{ df } & \multirow[t]{2}{*}{$\begin{array}{l}\text { Sig. }(2- \\
\text { tailed) }\end{array}$} & \multirow[t]{2}{*}{$\begin{array}{c}\text { Mean } \\
\text { Difference }\end{array}$} & \multirow[t]{2}{*}{$\begin{array}{l}\text { Std. Error } \\
\text { Difference }\end{array}$} & \multicolumn{2}{|c|}{$\begin{array}{l}95 \% \text { Confidence } \\
\text { Interval of the } \\
\text { Difference }\end{array}$} \\
\hline & & & & & & & & & Lower & Upper \\
\hline $\begin{array}{l}\text { Post } \\
\text { oral } \\
\text { test }\end{array}$ & $\begin{array}{l}\text { Equal } \\
\text { variances } \\
\text { assumed } \\
\text { Equal } \\
\text { variances not } \\
\text { assumed }\end{array}$ & 8.23 & .00 & $\begin{array}{r}12.25 \\
12.25\end{array}$ & 82 & .00 & -4.90 & .40 & -5.70 & -4.11 \\
\hline
\end{tabular}

At 0.05 level of significance

The above Table 3 results of Independent Samples T-test indicate that the p-value is 0.00 which is less than $t$ value of significance at 0.05 . Hence, the null hypothesis was rejected. From this, it is possible to say that there is a significant difference in the speaking performance between the students who were taught speaking skill with TBI and those who did not get such treatment of learning.

Lastly, to identify the performance difference between the pre and post-oral test of the group in general the calculated paired sample t-test was used for data analysis. To find out if the two groups were performing differently or in the same way, a comparison was made using the paired sample t-test. Now, let us revise the hypotheses raised at the beginning of this study and verify them.

HO: The task based instruction cannot improve student's speaking skill. Vs

H1: The task based instruction can improve student's speaking skill.

Table 4 The results of Paired Samples T-test

\begin{tabular}{|c|c|c|c|c|c|c|c|c|c|}
\hline & & \multicolumn{5}{|c|}{ Paired Differences } & \multirow[b]{3}{*}{$\mathrm{T}$} & \multirow[b]{3}{*}{ df } & \multirow{3}{*}{$\begin{array}{l}\text { Sig. (2- } \\
\text { tailed) }\end{array}$} \\
\hline & & \multirow[b]{2}{*}{ Mean } & \multirow[b]{2}{*}{ Std. Deviation } & \multirow{2}{*}{$\begin{array}{c}\text { Std. Error } \\
\text { Mean }\end{array}$} & \multicolumn{2}{|c|}{$\begin{array}{l}95 \% \text { Confidence } \\
\text { Interval of the } \\
\text { Difference }\end{array}$} & & & \\
\hline & & & & & Lower & Upper & & & \\
\hline Pair & $\begin{array}{l}\text { Post oral test } \\
\text { Pre oral test }\end{array}$ & 2.44 & 3.63 & .39 & 1.65 & 3.23 & 6.16 & 83 & .0 \\
\hline
\end{tabular}

\section{Hypothesis}

Ho: Mean of test two (post intervention test score) is equal to mean of test one (pre intervention test score). Vs $\mathrm{H}_{1}$ : not Ho or Mean of test two (post intervention test score) is greater than mean of test one (pre intervention test score).

Decision rule: reject Ho if $\mathrm{p}$ value $<\mathrm{t}$. Where $\mathrm{t}=0.05$,

The above Table results of Paired Samples T-test indicate that the p-value is 0.00 which is less than $t$-value of significance at 0.05 . Hence, Ho was rejected and concluded that mean of test two (post intervention test score) is greater than mean of test one (pre intervention test score). This indicates that there was an improvement of speaking skill of experimental group students as a result of teaching speaking skill by using task based instructions.

\section{Students' Perceptions towards the Practice of TBI on Speaking}

How the students perceive and react towards TBI process has a strong bearing on its effectiveness in contributing to students' speaking skills development. It is when students develop awareness about the use of TBI that they can take part in the teaching and learning of speaking using TBI. Having this in mind, data regarding the students' perceptions were gathered from the experimental group student's using a questionnaire and an interview right at the end of the study.

\section{Importance of TBI for Students' speaking in General}

Data regarding the reflections of students on the importance of TBI in general terms are presented and analyzed as follows. 
Table 5: Students' Perceptions towards the Importance of TBI to their speaking in General

\begin{tabular}{|c|c|c|c|c|c|c|c|c|c|c|c|c|c|}
\hline \multirow[t]{3}{*}{ No } & \multirow[t]{3}{*}{ Item } & \multicolumn{12}{|c|}{ Scale of response } \\
\hline & & \multicolumn{2}{|c|}{ SA } & \multicolumn{2}{|l|}{ A } & \multicolumn{2}{|c|}{ Undecided } & \multicolumn{2}{|c|}{ DA } & \multicolumn{2}{|c|}{ SD } & \multicolumn{2}{|c|}{ Total } \\
\hline & & $\mathrm{F}$ & $\%$ & $\mathrm{~F}$ & $\%$ & F & $\%$ & $\mathrm{~F}$ & $\%$ & $\mathrm{~F}$ & $\%$ & $\mathrm{~F}$ & $\%$ \\
\hline 1 & $\begin{array}{l}\text { Giving importance to the meaning } \\
\text { rather than form at first helps me to } \\
\text { use English in class more }\end{array}$ & 29 & 69 & 11 & 26 & 0 & 0 & 0 & 0 & 2 & 4.7 & 42 & 100 \\
\hline 2 & $\begin{array}{l}\text { Real life use of language can be } \\
\text { learnt through tasks (Here, task } \\
\text { means any communicative activity } \\
\text { that helps in language learning). }\end{array}$ & 16 & 38 & 20 & $\begin{array}{l}47 . \\
6\end{array}$ & 2 & 4.7 & 4 & 9.5 & 0 & 0 & 42 & 100 \\
\hline 3 & TBI improves my speaking skill & 27 & 64.2 & 11 & 26 & 0 & 0 & 2 & 4.7 & 2 & 4.7 & 42 & 100 \\
\hline 4 & $\begin{array}{l}\text { Knowing what to do during the TBI } \\
\text { helped me a lot in speaking task }\end{array}$ & 11 & 26 & 27 & 64.2 & 2 & 4.7 & 2 & 4.7 & 0 & 0 & 42 & 100 \\
\hline 5 & $\begin{array}{l}\text { TBI increased the number of people } \\
\text { who listen my speech. }\end{array}$ & 22 & 52.3 & 14 & 33.3 & 0 & 0 & 6 & 14.2 & 0 & 0 & 42 & 100 \\
\hline
\end{tabular}

Key: - SA= Strongly Agree, $\mathrm{A}=$ Agree, $\mathrm{UN}=$ Undecided, $\mathrm{DA}=$ Disagree, $\mathrm{SD}=$ strongly disagree

In item 1 of Table 5, almost all of the students have a positive attitude towards the task they practiced as they focus on meaning rather than form helps them to use English in class more. Among the 42(100\%) students, $40(95 \%)$ said that they agree to the fact that the task helped them to use English in class more. Only 2(4.7\%) students disagree.

In item 2 of Table 5, most of the students 36(85.6\%) agreed to the idea that real life use of language can be learnt through tasks.4 (9.5\%) students expressed their disagreement, while $2(4.7 \%)$ students refrained from commenting in either way. Thus, one can conclude that real life use of language can be learnt through tasks.

In item 3 of Table 5, the majority of the students $38(92.2 \%)$ they believed that TBI helped them to improve their speaking skill while 4(9.4\%) students disagreed to this. In item 4 of the Table 5 regarding the importance of teaching speaking by using TBI (knowing what to do during TBI process), 38 (90.25) students said that training is important. Only 2(4.7\%) student disagreed and 2(4.7\%) did not comment in either way. With respect to the importance of TBI in increasing the audience that listen the students' speech. In item 5 of the Table 5 , most of the students $36(85.6 \%)$ said that TBI increases the number of people who listen their speech.6 (14.2\%) students expressed their disagreement in this regard.

\section{Quality and Type of TBI Given and Used}

The type and quality of the TBI can influence the improvement of students' speaking performance. In order to find out what the students thought about the quality and types of the TBI given and used the perceptions of students were assessed.

Table 6: Students' Perceptions towards the Quality and Types of TBI Given and Used

\begin{tabular}{|c|c|c|c|c|c|c|c|c|c|c|c|c|c|}
\hline \multirow[t]{3}{*}{ No. } & \multirow[t]{3}{*}{ Item } & \multicolumn{12}{|c|}{ Scale of response } \\
\hline & & \multicolumn{2}{|c|}{ SA } & \multicolumn{2}{|c|}{ A } & \multicolumn{2}{|c|}{ Undecided } & \multicolumn{2}{|c|}{$\mathrm{DA}$} & \multicolumn{2}{|l|}{ SD } & \multicolumn{2}{|c|}{ Total } \\
\hline & & $\mathrm{F}$ & $\%$ & $\mathrm{~F}$ & $\%$ & $\mathrm{~F}$ & $\%$ & $\mathrm{~F}$ & $\%$ & $\mathrm{~F}$ & $\%$ & $\mathrm{~F}$ & $\%$ \\
\hline 1 & $\begin{array}{l}\text { This TBI gave me useful } \\
\text { improvement on my speaking } \\
\text { skill. }\end{array}$ & 11 & 26.1 & 23 & 54.7 & 2 & 4.7 & 4 & 9.5 & 2 & 4.7 & 42 & 100 \\
\hline 2 & This TBI bored me. & 14 & 33.3 & 22 & 52.3 & 4 & 9.5 & 2 & 4.7 & 0 & 0 & 42 & 100 \\
\hline 3 & $\begin{array}{l}\text { This TBI aroused my } \\
\text { imagination. }\end{array}$ & 6 & 14.2 & 28 & 66.6 & 2 & 4.7 & 4 & 9.5 & 2 & 4.7 & 42 & 100 \\
\hline 4 & $\begin{array}{l}\text { This TBI helped me extend } \\
\text { myself. }\end{array}$ & 14 & 33.3 & 22 & 52.3 & 2 & 4.7 & 2 & 4.7 & 2 & 4.7 & 42 & 100 \\
\hline 5 & $\begin{array}{l}\text { This TBI allowed me to control } \\
\text { what I was doing }\end{array}$ & 4 & 9.5 & 2 & 4.7 & 6 & 14.2 & 18 & 42.8 & 12 & 28.5 & 42 & 100 \\
\hline
\end{tabular}

In item 1 of table 6 , most of the students appeared to have a positive attitude towards the usefulness of TBI in improving their speaking skill in general. Regarding to this, $34(80.8 \%)$ students expressed their agreement, 6 $(14.2 \%)$ students stated their disagreement and only $2(4.7 \%)$ students refrained from giving idea in either way. In item 2 of table 4.7, with respect to the boringness of the method, 36(85. 6\%) students showed their disagreement, and only $2(4.7 \%)$ students showed their agreement to the method. The rest of $4(9.5 \%)$ students refrained from giving idea in either way. In item 3 of table 6 , regarding to this, 34(80.8\%) of them agreed that they could. 6 
(14.2\%) students disagreed to the idea. 2(4.7\%) students abstained from making comment. Thus, quite a good proportion of the students agreed to the fact that TBI can aroused their imagination. In item 4 of table 6 , concerning to this, 36(85. 6\%) students stated that this TBI helped them extend themselves, while only $2(4.7 \%)$ students refrained from giving idea. 4(9.5\%) students disagreed to the idea. In item 5 of table 6, concerning to this item30 (71.3\%) students agreed to the belief that this TBI allowed them to control what they were doing. Only $6(14.2 \%)$ students stated that TBI were not allowed them to control what they were doing and6 (14.2\%) students did not comment on this idea.

\section{Affective Benefits of Task based instruction}

Students' awareness of the affective benefits of TBI has a significant implication for the implementation of TBI. The data gathered in this regard are presented as follows.

Table 7: The affective benefit of TBI has a significant implication for the implementation TBI

\begin{tabular}{|c|c|c|c|c|c|c|c|c|c|c|c|c|c|}
\hline \multirow{3}{*}{ No } & \multirow[t]{3}{*}{ Item } & \multicolumn{12}{|c|}{ Scale of response } \\
\hline & & \multicolumn{2}{|c|}{ SA } & \multicolumn{2}{|l|}{$\mathrm{A}$} & \multicolumn{2}{|c|}{ Undecided } & \multicolumn{2}{|c|}{ DA } & \multicolumn{2}{|c|}{ SD } & \multicolumn{2}{|c|}{ Total } \\
\hline & & $\mathrm{F}$ & $\%$ & $\mathrm{~F}$ & $\%$ & $\mathrm{~F}$ & $\%$ & $\mathrm{~F}$ & $\%$ & $\mathrm{~F}$ & $\%$ & $\mathrm{~F}$ & $\%$ \\
\hline 1 & $\begin{array}{l}\text { Using TBI made me more active } \\
\text { in the speaking process. }\end{array}$ & 10 & 23.8 & 22 & 52.3 & 2 & 4.7 & 2 & 4.7 & 6 & 14.2 & 42 & 100 \\
\hline 2 & $\begin{array}{l}\text { This method of instruction } \\
\text { increased my confidence in } \\
\text { speaking. }\end{array}$ & 20 & $\begin{array}{l}47 . \\
6\end{array}$ & 12 & 28.57 & 2 & 4.7 & 6 & 14.2 & 2 & 4.7 & 42 & 100 \\
\hline 3 & $\begin{array}{l}\text { TBI reduced my fear/worry } \\
\text { about speaking skill. }\end{array}$ & 20 & $\begin{array}{l}47 . \\
6\end{array}$ & 16 & 38 & 0 & 0 & 4 & 9.5 & 2 & 4.7 & 42 & 100 \\
\hline 4 & $\begin{array}{l}\text { Practicing speech by using this } \\
\text { method was interesting. }\end{array}$ & 26 & 61.9 & 10 & 23.8 & 4 & 9.5 & 2 & 4.7 & 0 & 0 & 42 & 100 \\
\hline 5 & In general, I liked this method & 14 & 33.3 & 22 & 52.3 & 0 & 0 & 4 & 9.5 & 2 & 4.7 & 42 & 100 \\
\hline
\end{tabular}

In item 1 of Table 7, 32 (71\%) students agreed to the idea that using this method made them active, and only $2(4.7 \%)$ students said that had no idea. $8(18.9 \%)$ students said that they disagreed to the idea. In item 2 of Table 7, regarding confidence, 32(71\%) students agreed that TBI increased their confidence in speaking. While $2(4.7 \%)$ students made no idea, $8(18.9 \%)$ students expressed their disagreement to this idea. In item 3 of Table 7 , whether students believed that this method of instruction in speaking class reduced their fear or not, 36(85. 6\%) students stated that it did, while $6(14.2 \% \mathrm{~S})$ students stated that it did not reduce their fear. In item 4 of Table 7 , Concerning whether they liked the TBI in general, 36(85.6\%) students said that they liked while $6(14.2 \%)$ students expressed that they disliked it. From all these comments, it is possible to conclude that students liked the practice of TBI they were taking part in. It seems that they recognized the importance of the speaking skill and TBI to improve this skill.

\section{Analysis of the Interview}

In this study an interview was held with the experimental group students to collect the data by video recorded. In the analysis, the students' responses were categorized based on whether or not the students liked the TBI they were used in their speaking, whether the students perceived that TBI improved their speaking, and what areas of speaking the students' thought TBI could improve, and how the students incorporated TBI in speaking classes were analyses. The analyses of the students' responses were presented as follows.

Regarding whether or not the students liked the TBI practice, all the interviewees expressed their feeling that they liked the practice. It could be deduced from their responses that they appeared to perceive the uses of TBI. One of the students stated, "Yes I liked it, because ... it gives us an opportunity to speak without fear". Students' positive attitude towards the TBI practice was also implied in the students' responses. This was clearly indicated by a student who stated, "Yes, I liked so much ... because I learn so much things from it".

The next question was whether the students thought that using TBI can improves their speaking. The students responded positively. Among the interviewees one student (S1) said, "Yes of course. I would like to reply for this by the change I have made for myself, by the improvement I have made". Another student (S4) who seems to understand the fact that students are of different levels in their knowledge, expressed that the TBI improved their speaking. This means the slower students would get an advantage of learning from the clever ones during idea exchange. From these points, one can see that the students seemed to recognize the importance of TBI exchange of idea on speaking and, thus, had developed positive attitudes towards the practice.

Concerning the advantages of TBI giving and receiving comments during speaking classes, the students expressed the following as the benefits that can be generated from TBI. These are: "It helps to see the problems that students ('speakers') do not see; it reduces mistakes; it gives chance to see our problems and speak a good discourse; and it reduces fear". Emphasizing the benefit of TBI as collaboration in speaking was responded from the interviewee learners.

Regarding the areas of speaking (task achievement, fluency, discourse management, vocabulary, grammar, 
interactional activity and pronunciation) that TBI could address, the students seem to have different views. Some of the students stated that they mostly received and gave comments on fluency, discourse management and grammar improved as a result of TBI. Some doubted that students' ability to give comments on grammar; hence, TBI did not improve their grammar in speaking. One of the students replied (S7), "I think most of the students are commenting on fluency, discourse management and a little bit on grammar but most of the time they improve their pronunciation". While most of the students agreed that TBI could improve fluency, pronunciation and discourse management, some doubted that it improves grammar. Very few students said it improves organization, content and cohesion. It appears that students focus was on surface level features (fluency, pronunciation and grammar); they appeared to think that these areas could be improved by using TBI in speaking classes.

Students' general view about the use of TBI appears to be motivating. Five of the students replied saying that using TBI in speaking is very important to improve speaking skills. According to the students, TBI allowed a good opportunity to practice speaking and reduce fear of speaking. A comment made by one student reads, "In general it is very important thing and that it contributes many things for the teaching-learning process, and it should be continued".

Based on the responses of the students, it is possible to say that these students have developed a positive attitude towards this method of instruction. They also appeared to sense the uses of TBI in the process of speaking. The students also recognized, it could be said, the need to speak and do many practices in order to improve their skills of speaking. Besides, the motivating effect that the TBI offers is also another area of the students' awareness.

Regardless of the actual change in the overall speaking performance, the students seemed to think that TBI helped to improve speaking. They also stated that it helped them to practice speaking. In addition to these, the awareness the students developed about the use of TBI in speaking is another important aspect that this study revealed.

\section{Conclusion}

This study was conducted to find out the effectiveness of TBI on improving learners' speaking performance of EFL students. Based on the above findings, the following conclusions could be drawn.

There is an interaction between students using TBI, and speaking performance (fluency, grammar and discourse management). That is, TBI enhances students' speaking performance in the specified speaking features. Not only this, but also TBI enhances students' interaction in speaking there-by building up their interest and confidence.

TBI can be taken as one means to exercise the interactive approach to speaking in an EFL classroom. In other words, TBI gives the opportunity to speak and interact on producing the final fluent speech for the audience.

TBI was found to be helpful mainly for improving fluency, grammar and discourse management (cohesion and coherence). The students were unable to comment on task achievement, pronunciation, interactional activity and vocabulary.

From the students' questionnaire and interview it was observed that students' use of TBI was on a selective basis; they seemed to doubt the correctness of their speech comments.

Regardless of the accuracy and the scope of the TBI, TBI had a role to keep the students to communicate and speak using this method of instruction or without using this method of instruction. Thus, it has a beneficial effect in teaching speaking as an interactive process.

\section{References}

Abdulmjid Yousif. (2017).The Effect of Communicative Task Based Instruction on DevelopingStudents 'Oral Communication Skills. (PhD.Thesis) Sudan University of Science andTechnology: Khartoum

Atkins, J. Hailom B. and Nuru M. (1996). Skills Development Methodology Part 2. Addis Ababa: Addis Ababa University Press.

Baris K. (2005). The Effectiveness of Task-Based Instruction inthe Improvement of Learners' Speaking Skills . (MA Thesis) Ankara:Bilkent University

Bygate, M, Skehan, P. and Swain, M. (2001). Researching Pedagogic Tasks Second Language Byrne, D.( 1986). Techniques for Classroom Interaction. Singapore: Long Groups Ltd.

Candlin, C. (1987). "Towards Task-based Language Learning”. In Candlin, C. and Murphy, D. (Eds.) .1987. Language Learning Tasks. Englewood Cliffs, NJ: Prentice- Hall.

Creswell J.W.( 2002). Educational Research, Planning, Conducting and Evaluation Qualitativeand Quantitative Research, Boston: pearson Education.

Edwards, C. and Willis, J. (Eds.) (2005). Teachers Exploring Tasks in English Language Teaching. New York: Palgrave Macmillan.

Ellis, R. (2003). Task-based Language Learning and Teaching. Oxford: Oxford University Press. (2006). "The 
Methodology of Task-based Teaching". Asian EFL Journal. Vol. 8, No.3. http://www.asian-efljournal.com/Sept_06_re.php Accessed on 23/3/2008

Leaver, B. L. and Kaplan, M. A.( 2004). "Task-based Instruction in U.S Government Slavic Language Programs". In Leaver, B. L and Willis, J. R. (Eds.) 2004. Task based

Instruction in Foreign Language Education: Practices and Programs. Washington,D.C Georgetown University Press.

Littlewood, W. (1981). Communicative Language Teaching. Cambridge: CUP

Markee, N. (1997). Managing Curricular Innovation. Cambridge: Cambridge University Press.

Meseret Areaya. (2013). An Analysis of the Speaking Tasks of English for Ethiopia (MA Thesis). AAU

Morrison, K. R. B. (2001b). Randomised controlledtrials for evidence-based education: some Problemsin judging 'what works'. Evaluation and Research inEducation, 15 (2), 69-83.

Nunan, D. (1989). Designing Tasks for Communicative Classroom. Cambridge: CUP. (2007). "Task-based Language Teaching in Asian Context". Asian EFL Journal. Vol.8, No. 3. http://www.asian-efljournal.com/Sept_06_dn.php Accessed on 21/4/2008 Oliveira, C. P. (2004). "Implementing Task-based Assessment in a TEFL Environment". MA thesis unpublished

Oxford, R. (2006). "Task-based Language Teaching and Learning: An Overview”. Asian EFL Journal. Vol. 8, No. 3, pp. 250-270.

Prabhu, N.S. (1987). Second Language Pedagogy. Oxford: Oxford University Press.

Richards, J. and Rodgers, T. (2001). Approaches and Methods in Language Teaching. Cambridge: Cambridge University Press.

Shakika Rubaiat. (2018). The Effectiveness of Task Based Language Teaching in Improving ESL Learners' Reading and Writing Skills.(BA Thesis). BRAC University, Dhaka, Bangladesh

Sharma.R.(2000).Fundamentals of Educational Research. Mcerut:Inter Publishing House.

Shehadeh, A. (2005). "Task-based Language Learning and Teaching: Theories and

Applications". In Edward. C. and Willis, J. (Eds.) 2005. Teachers Exploring Tasks in English Language Teaching. New York: Palgrave Macmillan.

Sinatra, A. F. 2009. Optimizing Task- Based Activity to Improve Students' Speaking Ability. Unpublished Thesis, Universitas Sebelas Maret,solo

Skehan, P. (1996a). "A Framework for the Implementation of Task-based Instruction".

Journal of Applied Linguistics. Vol.17, No.1, pp.39-59. (1996b)."A Framework for the Implementation of Taskbased Instruction”. Journal of Applied Linguistics. Vol.18, No.1, pp.79-92.

Tegese Daniel.(2008). The Practicability of Task-Based in EFL Instruction in Higher

Institutes. (MA Thesis). Addis Ababa University.

Tirualem Ayalew, (2003). The classroom practices of learner-centered approach in second cycle primary school of Addis Ababa. A thesis submitted to the school of Graduate Studies of Addis Ababa University.

Wajnryb, R. (1992). Classroom Observation Tasks: A Recourse Book for Language Teachers and Trainers. Cambridge: Cambridge University Press.

Williams, M. and Burden, R. L. (1997). Psychology for Language Teachers. Cambridge: Cambridge University Press.

Willis, J. (1996). “A Flexible Framework for Task-based Learning”. In Willis, J. and Willis, D. (Eds.) 1996. 